http://jmscr.igmpublication.org/home/ ISSN (e)-2347-176x ISSN (p) 2455-0450 crossref DOI: https://dx.doi.org/10.18535/jmscr/v8i4.94

\title{
The Epidemiological Characteristics of an Outbreak of 2019 Novel Coronavirus Diseases (COVID-19) In Bangladesh: A Descriptive Study
}

\author{
Authors \\ Dr Irin Hossain, MPH*1, Prof. Dr Manzurul Haque Khan, PhD ${ }^{2 *}$, \\ Dr Md Shafiur Rahman, MPH $^{3}$, Dr Ashekur Rahman Mullick, MPH ${ }^{4 *}$, \\ Dr M M Aktaruzzaman, MPH $^{5}$ \\ ${ }^{1-3}$ National Institute of Preventive and Social Medicine (NIPSOM), Dhaka, Bangladesh \\ ${ }^{4}$ Delta Medical College and Hospital, Dhaka, Bangladesh \\ ${ }^{5}$ DGHS, Dhaka, Bangladesh \\ *Corresponding Author \\ Dr Irin Hossain, MPH \\ National Institute of Preventive and Social Medicine (NIPSOM), Dhaka, Bangladesh
}

\begin{abstract}
COVID-19 was first confirmed in Bangladesh in 8 March, 2020. Here, we report results of a descriptive, and exploratory analysis of all cases diagnosed as of 16 April, 2020. COVID-19 cases reported until 16 April, 2020 were extracted from official press briefings of IEDCR, DGHS, and MoHFW. Reports from different newspapers and online news portals were also reviewed. In Bangladesh, till 16 April, 2020, 17003 tests had been carried out which amounts 103 tests per million populations. These tests resulted in detection of 1572 confirmed COVID-19 cases over a period of 40 days. The female to male ratio of confirmed cases was 1:2.33. Of the total confirmed patients, $10 \%$ were 20 years of age or under, and $43 \%$ were in the age range of 21 to 40 years; elderly group over 60 years old were about $13 \%$. Most cases (about 48.9\%) reported that they lived in or had come to Dhaka within 14 days before the onset of illness or had been in close contact with any Dhaka resident. Healthcare providers constituted 4.83\% (76) of the detected cases and among them 85.5\% were doctors. Since the detection of the 1st case till 16 April, 2020, 106308 people were placed in home quarantine, 3875 were placed in institutional quarantine, and another 461 individuals had been placed in isolation. Among those who had been hospitalized, only $3.18 \%$ were discharged after recovery. With the numbers of deaths reaching 60, the case fatality rate (CFR) was 3.9\%.COVID-19 is spreading throughout Bangladesh. Testing for infection is both inadequate and not easily accessible. Infections are occurring in all age groups and case fatality is quite high. Healthcare workers especially doctors are possibly at highest risk because of their occupation.
\end{abstract}

Keywords: Epidemiological Characteristics, Outbreak, Novel corona virus, COVID-19.

\section{Introduction}

Since early December, 2019, a number of people who worked at or lived around the local seafood wholesale market in Wuhan, China initially contracted pneumonia of unknown cause that was followed by severe acute respiratory distress syndrome, acute respiratory failure, and other serious complications. On 7 January, 2020 the Chinese Center for Disease Control and Prevention identified a new corona virus from a 
throat swab sample of a patient. Subsequently World Health Organization (WHO) named this novel coronavirus as 2019-nCoV1.This corona virus belongs to large family of enveloped RNA virus and is highly contagious, and it spreads primarily through droplets of saliva or discharge from the nose when an infected person coughs or sneezes.2 Initially it is thought the virus had been transmitted from animal to humans. Subsequently the virus had travelled around the globe as air droplet, and ultimately human-to-human transmission continues to be reported from different parts of the world.3 On 29 December, 2019, World Health Organizations (WHO) addressed lower respiratory tract affecting coronavirus as 2019 novel coronavirus or just simply COVID-19. Outbreaks in different countries prompted the Ministry of Health and Family Welfare (MoHFW) Bangladesh to equip its PCR (Polymerase chain reaction) lab at IEDCR (Institute of Epidemiology, Disease Control, and Research) for testing samples from suspected COVID-19 cases for 2019-nCoV. The first confirmed cases of COVID-19 Bangladesh was reported on 8 March, 2020.4 PCR is a method used widely in molecular biology to make millions to billions of copies of a specific DNA sample rapidly, allowing scientists to take a very small sample of DNA and amplify it to a large enough amount to study in detail.

\section{Materials and Methods}

COVID-19 cases reported until 16 April, 2020 were extracted from official press briefings of IEDCR, DGHS (Director General of Health Service) and MoHFW. Reports from different local newspapers and online news portals were also reviewed. ${ }^{5-14}$ Analysis included patient characteristics; number of diagnostic tests (Real time RT-PCR) conducted and their results; overall quarantine and isolation situation; and case fatality in Bangladesh. In Bangladesh from 8 March, 2020 to 17 March, 2020 IEDCR arranged daily official press briefing on behalf of MoHFW to describe the daily situation of COVID-19.
Thereafter DGHS and IEDCR jointly held press briefing on the issue and the information was made available in the MoHFW-DGHS webpage. We extracted all the data from the case reporting system, and removed the personally identifiable information of all cases during the analysis to protect personal privacy. If a patient was engaged in any form of work in a medical institution, the occupational variables are classified as health-care provider (that is, this category includes not only doctors and nurses, but anyone working in a medical facility); if the patient had recently lived in Dhaka, or had traveled, or has been close contact with anyone living in Dhaka, they are classified as Dhaka- related exposures. This data analysis relates to information collected from 8 March, 2020 to 16 April, 2020 in relation to outbreak handling of COVID-19 epidemic situation in Bangladesh.

\section{Results}

In Bangladesh real time RT-PCR (real time Reverse Transcription-Polymerase Chain Reaction) for diagnosis of COVID-19 was initiated in early March, and the first 3 cases were reported on the 8 March, 2020. ${ }^{4}$ Real time RTPCR is a nuclear-derived method for detecting the presence of specific genetic material from any pathogen, including a virus. Till date (16 April, 2020), 17003 tests had been carried out which sums up to be 103 tests per million population. These tests resulted in detection of 1572 confirmed COVID-19 cases over a period of 40 days (Figure 1). The female to male ratio of confirmed cases was 1:2.33. Of the total patients, $10 \%$ were 20 years of age or under, and $43 \%$ were in the age range of 21 to 40 years. Elderly group was over 60 years old accounted about $13 \%$ of the detected cases (Figure 2). At present COVID-19 has been detected in 53 districts in all 8 divisions of Bangladesh (Figure 3). Most cases (48.9\%) reported that they lived in or had come to Dhaka within 14 days before the onset of illness, or had been in close contact with any of Dhaka resident. The Dhaka cases are scattered throughout the city 
with higher number of cases in Wari, Tolarbagh, Dhanmondi, Lalbagh, Mirpur, Mohammadpur, Uttara, Basabo, and Jatrabari (Figure 4). Healthcare providers constituted $4.83 \%$ (76) of the detected cases and among them $85.5 \%$ were doctors. Since the detection of the $1^{\text {st }}$ case till 16 April 2020, 106308 people were placed in home quarantine, 3875 were placed in institutional quarantine and another 461 individuals had been placed in isolation. Among those who had been hospitalized only $3.18 \%$ were discharged after they tested negative for the virus in 2 consecutive sets of nasopharyngeal throat swabs collected $\geq 24$ hours apart. With the numbers of deaths reaching 60 the Case fatality rate (CFR) was 3.9\%. Initially the CFR was high but in recent dates it had been diluted by increase in case detection because if increase in the number of testing (Figure $1 \& 5$ ).

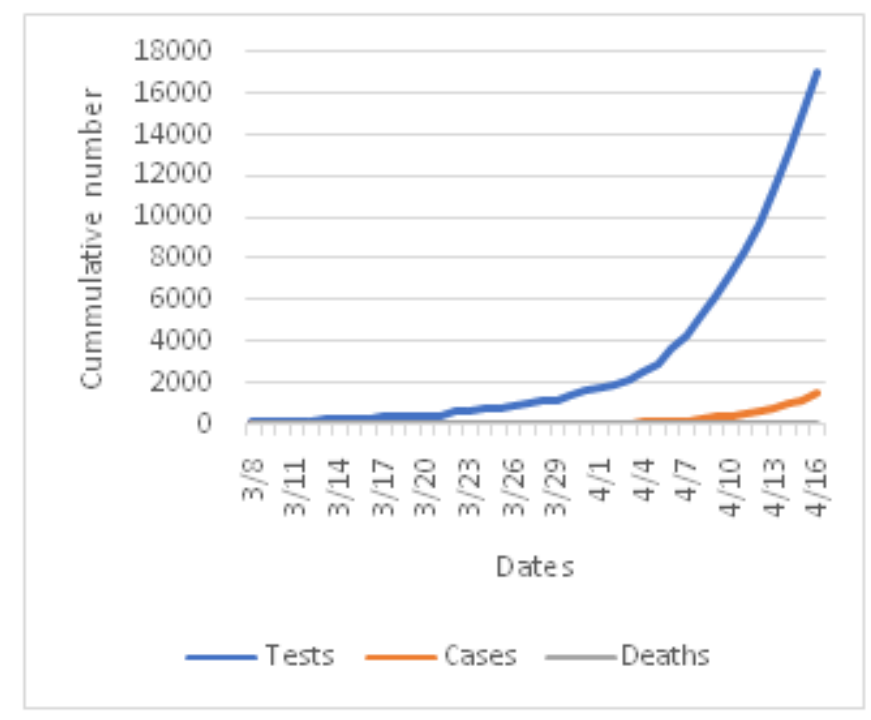

Figure-1: RT-PCR tests, COVID-19 cases and deaths

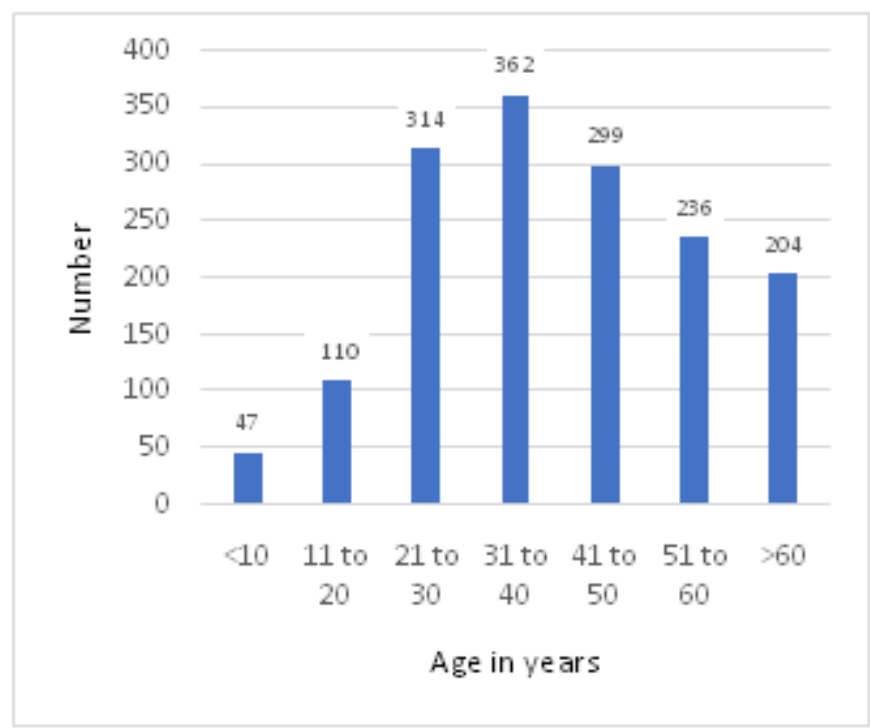

Figure-2: Age distribution of COVID-19 patients 


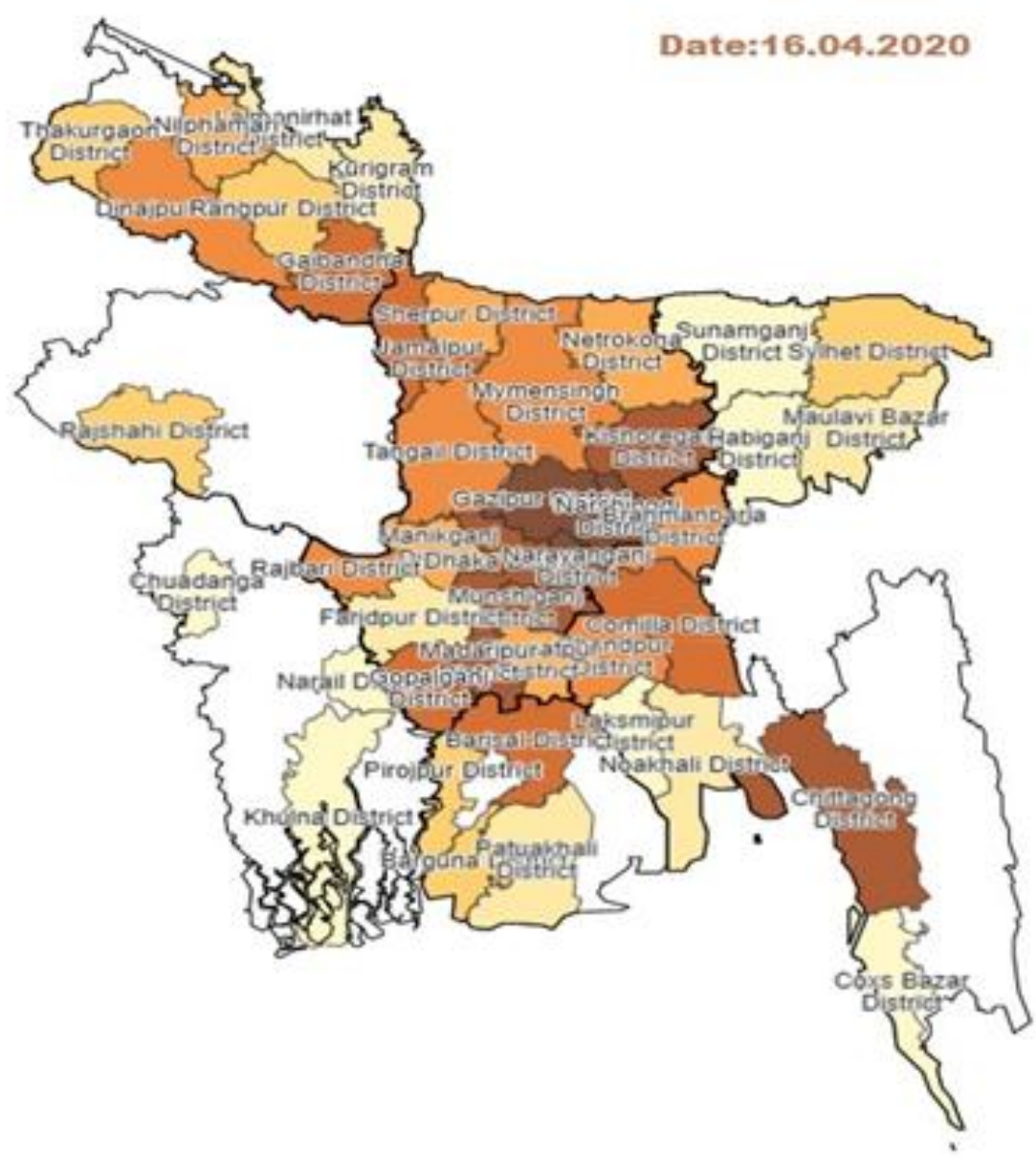

Figure-3: District-wise distribution of COVID-19 cases as on 16 April, 2020

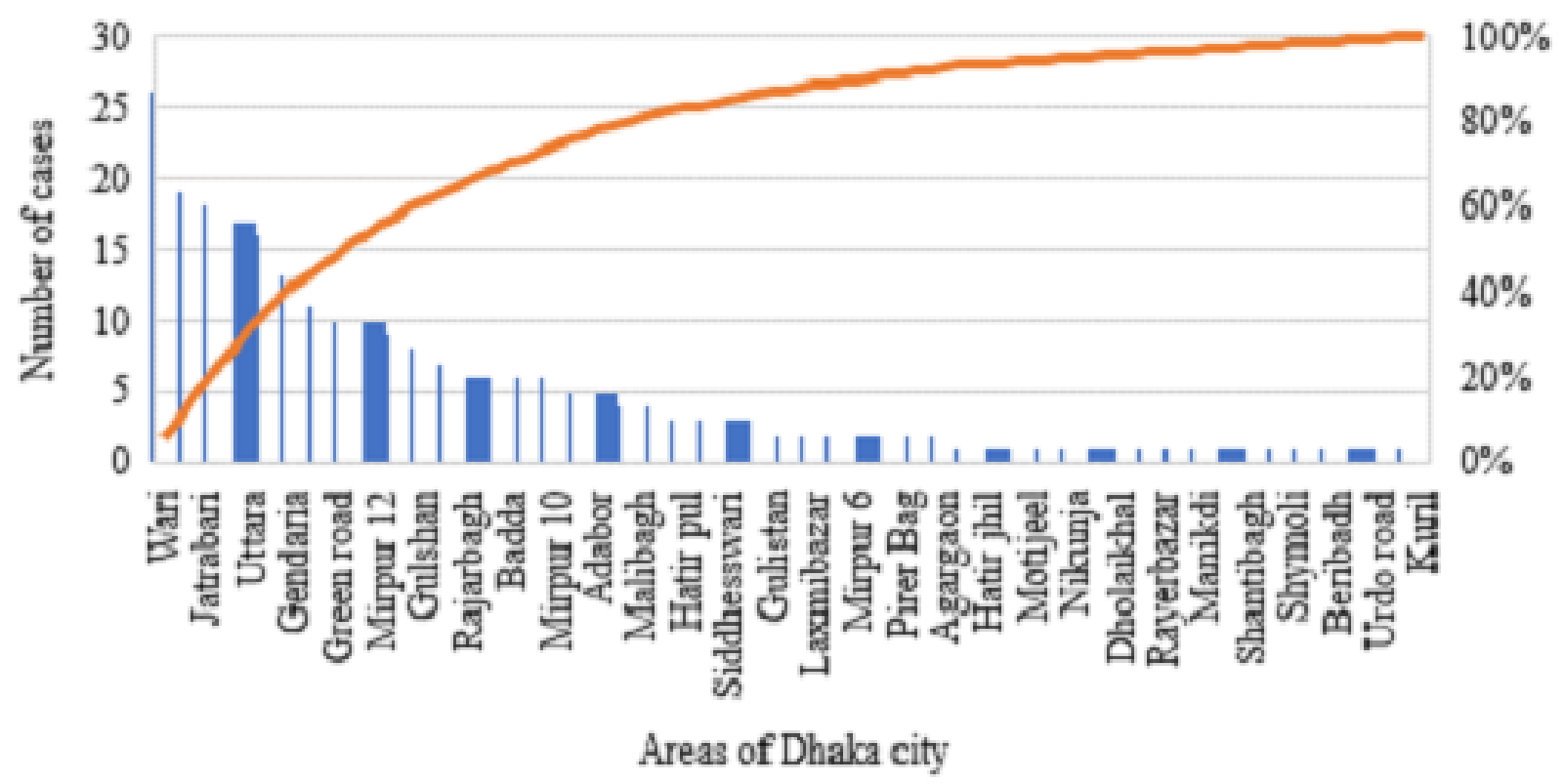

Figure-4: COVID-19 cases detected in different areas of Dhaka city 


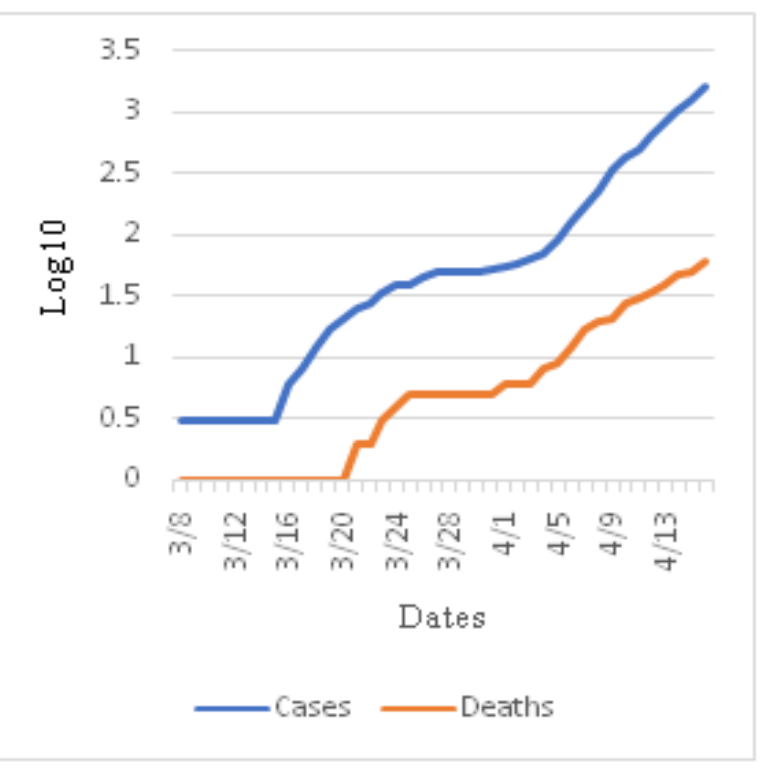

Figure-5: COVID-19 cases and deaths

\section{Discussion}

In December 2019, a cluster of severe acute respiratory illness (atypical pneumonia), occurred in Wuhan, Hubei Province, China. ${ }^{15-19}$ On 31 December, 2019, the WHO, China Country Office was informed of the cases of pneumonia of unknown etiology. Later on, 7 January, 2020 The Chinese authorities identified a new type of coronavirus as the causative agent, which was later named as 2019 n-CoV. By 20 January, 2020 patients surfaced in some parts of China, Japan, Thailand, and Republic of Korea. On 2 January, the incident management system was activated across the three levels of World Health Organization (country office, regional office, and headquarters) and informed other countries about the situation. ${ }^{20}$ As the virus continued to spread, WHO on 22 January assessed the risk of the event to be high at the global level. ${ }^{21}$ Though there was increasing discussions of atypical pneumonia and its possibility of spread, preparation for facing outbreaks was real slow. On the $1^{\text {st }}$ day of February, 312 Bangladeshis returned from Wuhan the epicenter of covid-19. ${ }^{22}$ This group of returnees were formally quarantined, but thereafter groups of Bangladeshis who had been returning from the virus affected countries i.e. Italy were simply screened from fever and allowed to go to their residences with a request to keep themselves isolated from others for 14 days. None of them were tested for $\mathrm{n}-\mathrm{CoV}-19$ soon after arrival. Among them some could have had asymptomatic infection and played the role of infection spreaders. The ones being asymptomatic had flaunted quarantine and were busy socializing and moving around different parts of the country. ${ }^{23,24}$ Bangladesh took 45 days to roll out its first test for virus detection since being informed by WHO (World Health Organization) of the global emergency. Throughout March and early April, tests appear to have restricted or highly selective (Figure 1) and was available only in IEDCR. In April, ultimately initiative was taken to increase the number of tests and the capacity of selected government facilities to carryout testing. The private healthcare sector remains to be taken onboard. In regard to testing, Bangladesh ranks the second lowest among Asian countries having undertaken 103 tests per million population (as on 16 April, 2020). In recent days as testing continues, cases have been found to have increased manifold (Figure 1). Besides the movements of expatriates, movement of large groups of people to and from Dhaka ${ }^{22-27}$ have possibly aided the rapid spread of the virus in the population many parts of the country (Figure 3). As for ICU (Intensive care unit) beds and ventilators in the government hospitals, the picture is grim both in term of number and functionality. ${ }^{28,29}$ nCoV-19 infections in healthcare workers have been reported and among them most $(85.5 \%)$ were doctors. Infection in healthcare communities may have been because of the close contact to asymptomatic individuals seeking medical attention for other causes; nonavailability, inadequacy, and inefficiency of PPEs (Personal protective equipment); and inadequate training, and monitoring of PPE use.

\section{Conclusions \& Recommendations}

COVID-19 is spreading throughout Bangladesh. Testing for infection is inadequate and at the same time not easily accessible. Number of per day tests needs to be ramped up exponentially and 
immediately. Infections are occurring in all age groups and case fatality is quite high. Healthcare workers especially doctors and nurses are possibly at highest risk because their occupation puts them in front line of close contact to patients. PPEs that complies with WHO (World Health Organization) or NIOSH (National Institute for Occupational Safety and Health) standards and useable in scenarios of droplet spread need to be made available to healthcare workers in adequate number. Facilities for management of moderate and severe case have to be boosted; adequate isolation facilities, ICUs, ventilators, and other relevant equipment need to be put into place. Private healthcare sector needs to be on board for diagnosis of infection and management of moderate and severe cases. Time is running out, if response to the threat is flawed or delayed, the country will have to pay dearly.

\section{References}

1. Chen N, Zhou M, Dong X, Qu J, Gong F, Han Y, et al. Epidemiological and clinical characteristics of 99 cases of 2019 novel coronavirus pneumonia in Wuhan, China: a descriptive study. Lancet [Internet]. 2020; 395(10223):507-13. http://dx.doi.org/10.1016/S0140-6736 (20)30211-7

2. World Health Organization. 2020. Coronavirus. https://www.who.int/healthtopics/coronavirus\#tab=tab_1. Accessed on 27 March, 2020

3. W.H.O. Situation report - 4 Novel Coronavirus (2019-nCoV) 24 January 2020. https://www.who.int/docs/defaultsource/coronaviruse/situationreports/20200124-sitrep-4-2019ncov.pdf?sfvrsn=9272d086_8

4. Bangladesh confirms first three coronavirus cases. Somoy English Desk. $2020 \quad$ March 16:20. https://en.somoynews.tv/5897/news/Bangl adesh-confirms-first-three-coronaviruscases
5. Dashboard of Directorate General of Health Services (DGHS), The Government Republic of Bangladesh. 2020. https://www.dghs.gov.bd/index.php/bd/. Accessed on 26 March, 2020

6. Coronavirus COVID-19 Dashboard. 2020.http://103.247.238.81/webportal/pag es/covid19.php. Accessed on 28 March, 2020

7. 2 more coronavirus cases detected in Bangladesh: Health Minister. Somoy English Desk. $202014^{\text {th }}$ March 22:17. https://en.somoynews.tv/6115/news/2more-coronavirus-cases-detected-inBangladesh-Health-Minister

8. 2,314 in quarantine, 10 in isolation: IEDCR. Somoy English Desk. $202015^{\text {th }}$ March $14: 30$. https://en.somoynews.tv/6128/news/2314in-quarantine-10-in-isolation-IEDCR

9. 3 more Covid-19 patients detected in Bangladesh; all of same family: IEDCR. Somoy English Desk. $202016^{\text {th }}$ March 13:00.

https://en.somoynews.tv/6161/news/3more-Covid-19-patients-detected-inBangladesh-all-of-same-family-IEDCR

10. Two more Covid-19 patients detected in Bangladesh: IEDCR. Somoy English Desk. $2020 \quad 17^{\text {th }} \quad$ March $12: 24$. https://en.somoynews.tv/6202/news/Twomore-Covid-19-patients-detected-inBangladesh-IEDCR

11. Three more Covid-19 patients detected in Bangladesh: DGHS. Somoy English Desk. $2020 \quad 19^{\text {th }} \quad$ March $12: 55$. https://en.somoynews.tv/6293/news/Threemore-Covid-19-patients-detected-inBangladesh-DGHS

12. Bangladesh reports another coronavirus death. Somoy English Desk. $202021^{\text {st }}$ March 14:31. https://en.somoynews.tv/6364/news/Bangl adesh-reports-another-coronavirus-death 
13. 4 including 2 physicians test positive for Covid-19. Dhaka Tribune. $202027^{\text {th }}$ March 11:27. Available at: https://www.dhakatribune.com/bangladesh /2020/03/27/coronavirus-4-more-testedpositive-in-bangladesh-total-infected-48

14. Bangladesh reports first coronavirus death. United News of Bangladesh. 2020 March 3:45.https://unb.com.bd/category/Banglade sh/bangladesh-reports-first-coronavirusdeath/47361

15. Lu H, Stratton CW, Tang YW. Outbreak of pneumonia of unknown etiology in Wuhan China: the mystery and the miracle [published January 16, 2020]. $J$ Med Virol. 2020. doi:10.1002/jmv.25678PubMedGoogle Scholar

16. Hui DS, I Azhar E, Madani TA, et al. The continuing 2019-nCoV epidemic threat of novel coronaviruses to global health: the latest 2019 novel coronavirus outbreak in Wuhan, China [published January 14, 2020]. Int J Infect Dis. 2020; 91:264-266.

doi:10.1016/j.ijid.2020.01.009PubMedGo ogle ScholarCrossref

17. Wuhan Municipal Health Commission. Report of novel coronavirus-infected pneumonia in China. Published January 20, 2020. Accessed January 31, 2020. http://wjw.wuhan.gov.cn/front/web/showD etail/2020012009077

18. Paules CI, Marston HD, Fauci AS. Coronavirus infections-more than just the common cold [published January 23, 2020]. JAMA.

Doi:

10.1001/jama.2020.0757

Article Google

19. Wuhan Municipal Health Commission. Report of clustering pneumonia of unknown etiology in Wuhan City. Published December 31, 2019. Accessed January

31 , 2020.
http://wjw.wuhan.gov.cn/front/web/showD etail/2019123108989

20. W.H.O. Situation report - 1. Novel Coronavirus (2019-nCoV) 21 January 2020.

21. https://www.who.int/docs/defaultsource/coronaviruse/situationreports/20200121-sitrep-1-2019ncov.pdf?sfvrsn=20a99c10_4

22. W.H.O. Situation report - 4 Novel Coronavirus (2019-nCoV) 24 January 2020 https://www.who.int/docs/defaultsource/coronaviruse/situationreports/20200124-sitrep-4-2019ncov.pdf?sfvrsn=9272d086_8

23. 312 Bangladeshis return from China. Independent Online/BSS Published by Independent Publications Limited at Media Printers, 446/H, Tejgaon I/A, Dhaka-1215. Beximco Media Complex, 149-150 Tejgaon I/A, Dhaka-1208, Bangladesh. GPO Box No. 934, Dhaka1000. MODIFIED: 2 February, 2020 09:19:08 AM

24. Returnees from abroad fined for violating quarantine rules in dists. The Financial Express. March 20, 2020. International Publications Limited. Tropicana Tower ( $4^{\text {th }}$ floor), 45 Topkhana Road, GPO Box: 2526

Dhaka-1000. https://thefinancialexpress.com.bd/national /returnees-from-abroad-fined-forviolating-quarantine-rules-in-dists1584682983

25. Returnee expats advised to contact police. The New Nation. Wednesday, March 25, 2020. New Nation Printing Press. 1 R.K. Mission Road, Ittefaq Bhaban ( ${ }^{\text {rd }}$ floor), Dhaka-1203, Bangladesh. http://m.thedailynewnation.com/news/250 725/returnee-expats-advised-to-contactpolice

26. Waves of RMG workers return to Dhaka from Mymensingh. Dhaka Tribune. April 3rd, 2020. Dhaka Tribune. 8/C, FR Tower, 
Panthapath, Dhaka 1207, Bangladesh. https://www.dhakatribune.com/bangladesh /nation/2020/04/03/waves-of-rmgworkers-return-to-dhaka-frommymensingh

27. RMG workers returning Dhaka to save jobs amid virus fear. The Financial Express. April 04, 2020. International Publications Limited. Tropicana Tower (4 ${ }^{\text {th }}$ floor), 45 Topkhana Road, GPO Box: 2526 Dhaka-1000. https://thefinancialexpress.com.bd/national /rmg-workers-returning-dhaka-to-savejobs-amid-virus-fear-1586003905

28. Naimul Karim. Thousands of Bangladeshi garment workers ordered home as factories stay closed. Reuters. April 5, 2020. https://www.reuters.com/article/us-healthcoronavirus-bangladeshworkers/thousands-of-bangladeshigarment-workers-ordered-home-asfactories-stay-closed-idUSKBN21N0QU

29. Sheikh SabihaAlam. Only 67 ICUs in Dhaka for treating COVID-19 patients. Prothomalo 8 April 2020. https://en.prothomalo.com/bangladesh/city /only-67-icus-in-dhaka-for-treating-covid19-patients

30. Syed Samiul Basher Anik. Coronavirus: Bangladesh facing severe ventilator shortage. Published at 09:21 am April 14th, 2020 Dhaka Tribune. 8/C, FR Tower, Panthapath, Dhaka 1207, Bangladesh https://www.dhakatribune.com/bangladesh /2020/04/14/coronavirus-bangladeshfacing-severe-ventilator-shortag. 